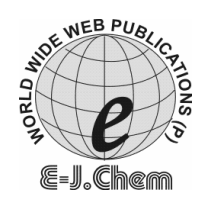

ISSN: 0973-4945; CODEN ECJHAO E-Journal of Chemistry

http://www.e-journals.net

2010, 7(4), 1266-1273

\title{
Physicochemical Characteristics of Pennar River, A Fresh Water Wetland in Kerala, India
}

\author{
P.V. JOSEPH and CLARAMMA JACOB* \\ Department of Zoology, K.E. College, Mannanam Kottayam -686561, Kerala, India. \\ *P.G. Department of Zoology, Alphonsa College, Pala, Kottayam -686574, Kerala, India. \\ claropoo@yahoo.com
}

Received 10 January 2010; Accepted 5 March 2010

\begin{abstract}
Some physicochemical characteristics of a fresh water wetland were investigated. The analysis was carried out for a period of two years. Physical parameters such as colour, odour, temperature, electrical conductivity (EC) total suspended solids (TSS) total dissolved substances (TDS), total solids (TS), turbidity and chemical parameters such as $\mathrm{pH}$, alkalinity, hardness, dissolved oxygen (DO), biochemical oxygen demand (BOD), chemical oxygen demand (COD), chloride, salinity, flouride, phosphate \& nitrate were examined. Results of the study indicated that water in Pennar river is highly contaminated and not safe for drinking. Uncontrolled use of chemical fertilizers and pesticides, unscrupulous dumping of domestic wastes are the major causes of deterioration of water. Poor quality of drinking water was recorded as the major risk factor for the large-scale water-borne diseases in the area.
\end{abstract}

Keywords: Pennar river, Physical, Chemical, Microbial characteristics.

\section{Introduction}

Water is one of the most common yet the most precious resource on earth without which there would be no life on earth. Pollution is a serious problem as almost $70 \%$ of India's surface water resources and a growing number of its groundwater reserves have been contaminated by biological, organic and inorganic pollutants. In South Asian countries such as Nepal, India and Bangladesh, pollution of rivers is more severe and critical near urban stretches due to huge amounts of pollution load discharged by urban activities. The Bagmati River in the Kathmandu valley, Yamuna River at Delhi, Buriganga River of Dhaka, Tamiraparani River and Ruva River, suffer from severe pollution ${ }^{1-3}$. Water of river Hindon was found to be more polluted than river Narmada ${ }^{4}$. Microbial analysis of fecal coliforms in Sasthamcotta Lake indicated that the water was contaminated with human excreta ${ }^{5}$. 
The pollution of Pamba River is due to the Sabarimala pilgrimage, free flow of sewage, domestic waste and faecal matters into the river and intrusion of sea water ${ }^{6}$. The Meenachil River has a length 78 k.m flowing through Kottayam district, Kerala. The river flows in a westerly direction till it reaches Kottayam. Then it splits up in to numerous interconnecting water courses and finally joins with backwaters of Vembanad Lake by the way of four tributaries namely Kavanar, Kaipuzha Ar, Kodoor Ar and Pennar. The Pennar River, one of the tributaries Meenachil River has different water channels which spread over Kumaranalloor, Aymanam, Arpookara, Athirampuzha, Neendoor, Vechoor, the western villages of Kottayam district.

\section{Experimental}

The Pennar is the study area from where four different site areas were selected on the basis of land use. Following are the site area: Boat jetty area (Populated area), Pumping station (Agricultural area), Pennar Kaipuzha river junction. (Coconut palm area) \& Oil palm area. Surface water and sub surface water samples were collected for the physicochemical analysis. The prime investigation is to identify the factors related to poor quality of Pennar river.

The following physical parameters were selected to assess the quality of water in Pennar River such as colour, odour, temperature, secchi disc transparency (SDT), euphotic limit, turbidity, electrical conductivity (EC), total suspended solids (TSS), total dissolved substances (TDS) and total solids (TS). Chemical parameters studied were $\mathrm{pH}$, alkalinity, hardness, dissolved oxygen (DO), biochemical oxygen demand (BOD), chemical oxygen demand (COD), chloride, salinity, flouride, phosphate \& nitrate. Standard procedures were used for the analysis.

\section{Results and Discussion}

The physical, chemical, bacterial and fungal characteristics of Pennar River were evaluated during pre-monsoon, monsoon and post monsoon seasons. The observations and results are represented by following tables and graphs.

The present study revealed that the quality of water in different sites of the Pennar river is not same. It also showed seasonal variations. Most of these effects are due to anthropogenic activities. The water body is polluted from the near by agricultural fields-vast stretches of paddy field, coconut \& oil palm plantations. Nearness to medical college and boat service through Pennar River are other contributing factors.

\section{Physical factors}

About temperature parameter, highest degree of atmospheric temperature recorded in the month of May (Pre-monsoon period- Figure 1), it was the end of summer season and lowest temperature experienced in post-monsoon period, and it was after a long monsoon period and the onset of winter season. When surface and subsurface (below one meter) water temperatures are compared, subsurface temperature is slightly lower than surface temperature. In general water temperature is closely related to atmospheric conditions and surface water is directly influenced by atmospheric temperature. In monsoon period both atmospheric and water temperatures are lower.

Colour of the water body ranged from light yellow, yellow, brown, deep brown and coffee brown. Coconut palm area \& Oil palm area showed deep colours throughout the year due to organic pollution, algal growth, erosion etc. Pumping station also showed deep coffee brown colour especially just before paddy cultivation (pumping from paddy field with high content of mud and silt). 


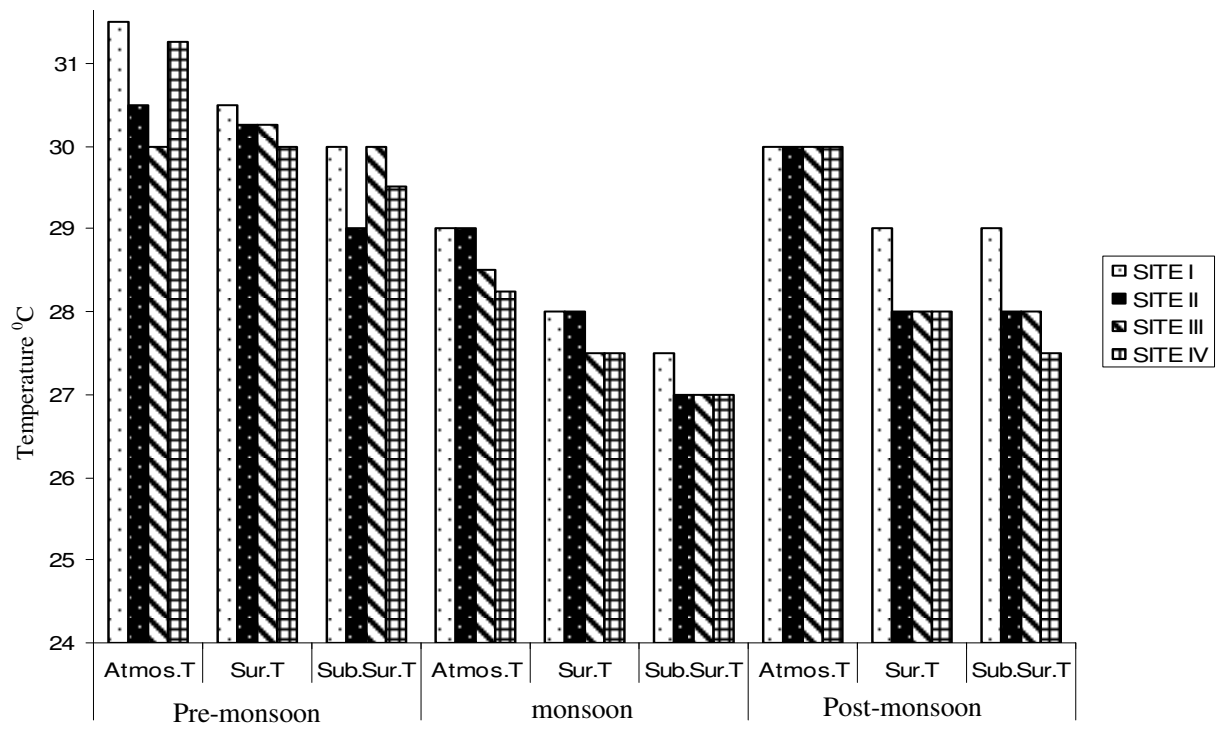

Figure 1. A comparison of atmospheric, surface and subsurface temperatures

Secchi disc transparency (SDT) and light penetration in these sites provided valuable information about the condition of the water, eg. algal growth, organic pollution, erosion etc. All the sites had very high turbidity. This may be due to the agricultural discharges and inorganic and organic matter present in the water as result of the erosive action of the flowing waters ${ }^{7}$. Water quality of Pennar River is varying according to seasons, agricultural practices, land utilization and presence of planktons. In the coconut palm area \& oil palm area (Figure 2) light penetration is very less. During pumping period paddy field area also exhibited high turbidity. When SDT is least turbidity is high. SDT and euphotic limit are directly proportional and Turbidity is inversely proportional.

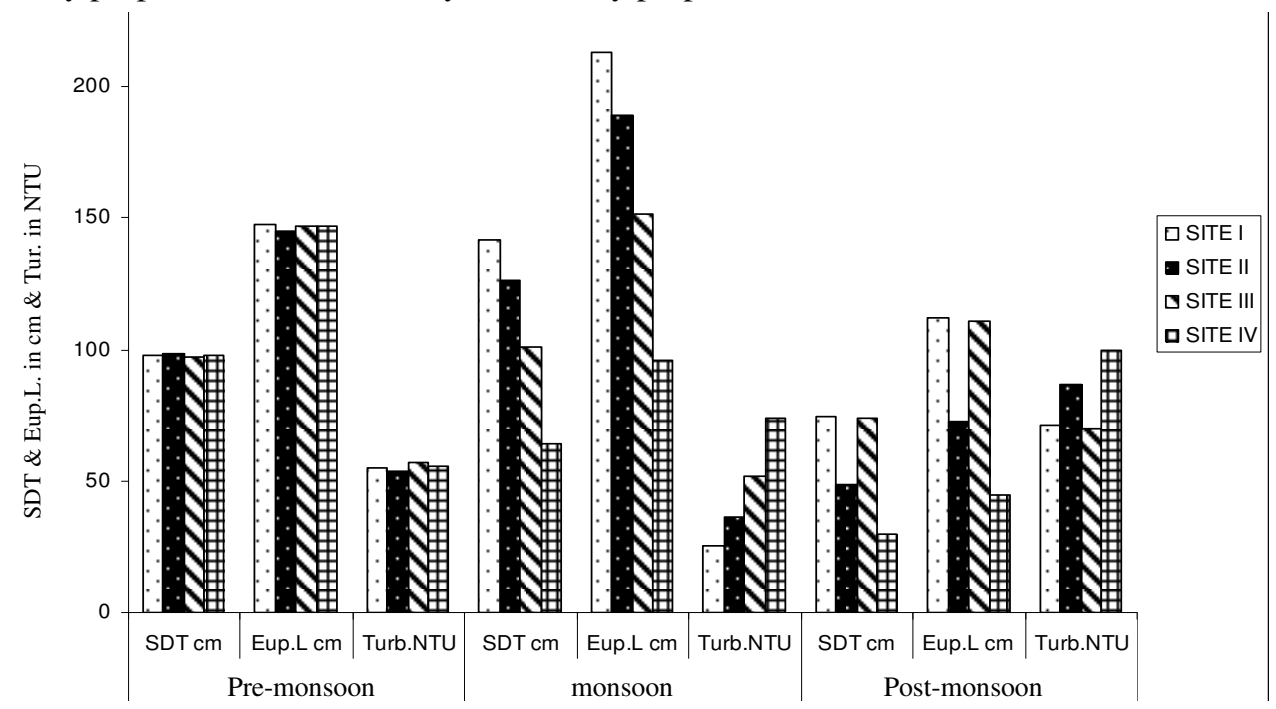

Figure 2. Relation between SDT, euphotic limit and turbidity in various seasons 
Total suspended solids (TSS), Total dissolved solids (TDS) and Total solids (TS) are always high in the coconut palm area and oil palm area. Coconut palm area is second in this matter (Figure 3). Readings show a clear cut positive correlation of high degree of organic matter and algal growth.

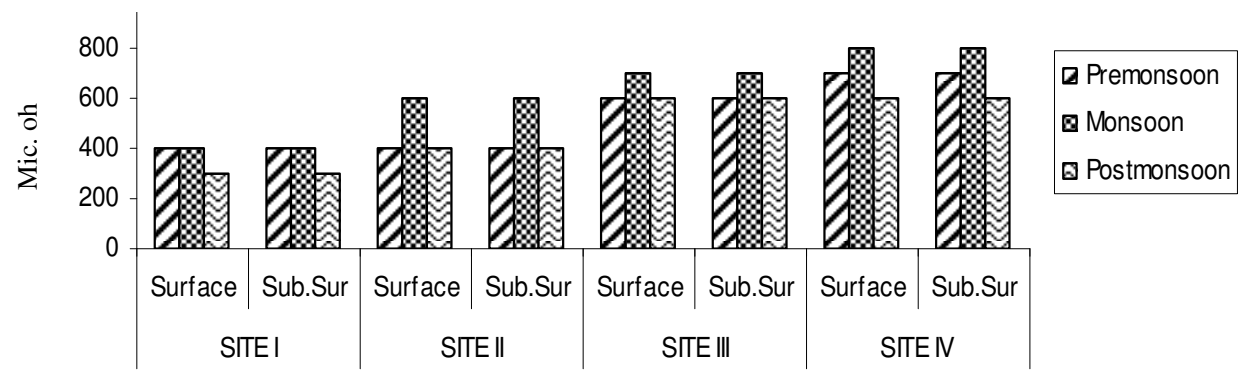

Figure 3. Electrical conductivity in different sites and seasons

Water in the coconut palm area \& oil palm area sites possessed bad odors. Fishy or phenolic odors were experienced at different times of the study period. Electrical conductivity (EC) is always high in the sites coconut palm area and oil palm area which is positively related to high quantity of dissolved salts (Figure 4). Another notable point is that EC is more pronounced in the month of August. This may be due to the high influx of surface run off monsoon rains.

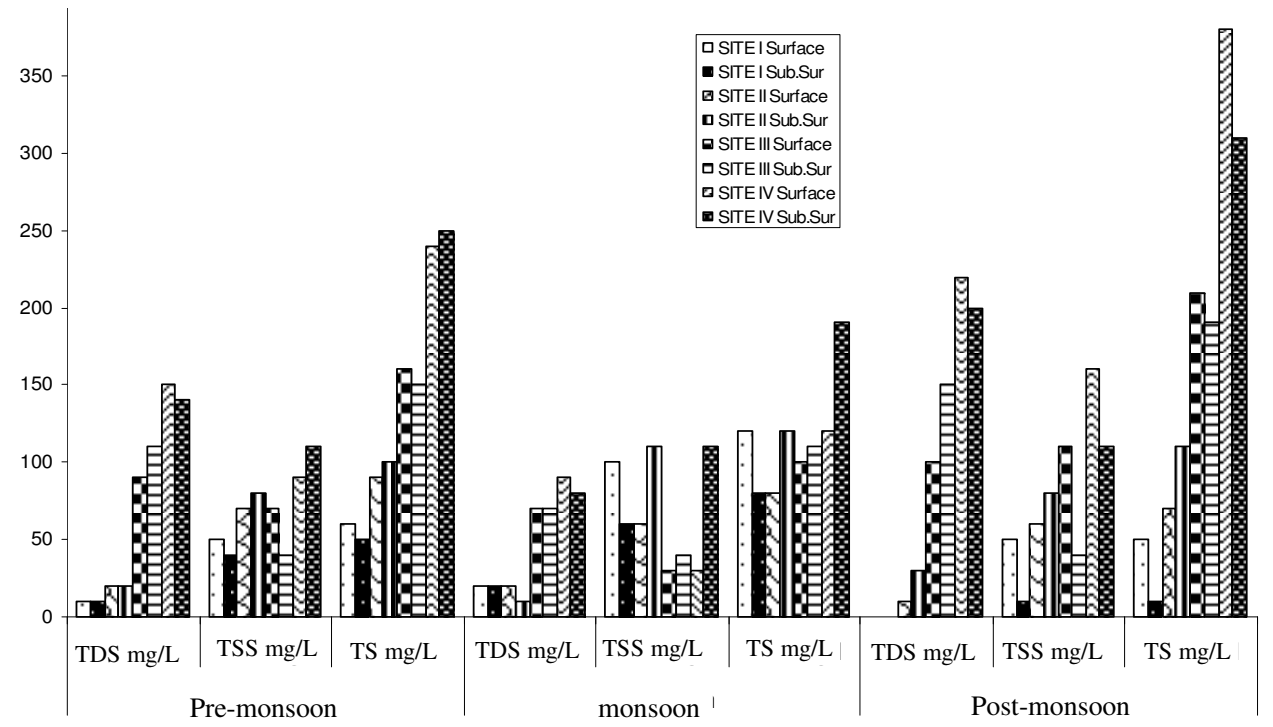

Figure 4. TDS, TSS and TS of different sites in different seasons

\section{Chemical factors}

(Table 1) In all site areas water sample is acidic. Water which has a $\mathrm{pH}$ value of more than 9 or less than 4.5 becomes unsuitable for most life forms and also for most other uses. In the present study $\mathrm{pH}$ lies between 4.7 and 6.1 i.e., the value observed is within the desirable limit. In the pre monsoon period flow rate of water is slightly slower and showed a slight increase in acidity in all sites. 
Table 1. Chemical characteristics of Pennar river in different seasons

\begin{tabular}{|c|c|c|c|c|c|c|c|}
\hline 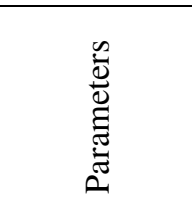 & Land use & & 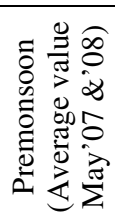 & 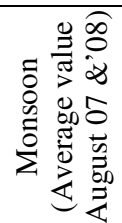 & 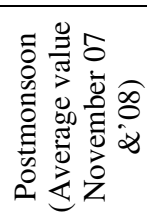 & 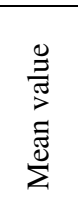 & 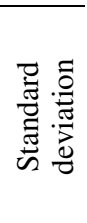 \\
\hline \multirow{8}{*}{$\mathrm{pH}$} & \multirow[t]{2}{*}{ Populated area } & Surface & 4.7 & 5.7 & 6 & 5.5 & 0.56 \\
\hline & & Subsurface & 4.8 & 5.9 & 5.9 & 5.5 & 0.52 \\
\hline & \multirow[t]{2}{*}{ Paddy cultivation } & Surface & 4.8 & 5.7 & 5.6 & 5.4 & 0.40 \\
\hline & & Subsurface & 4.9 & 5.9 & 5.7 & 5.5 & 0.43 \\
\hline & \multirow[t]{2}{*}{ Coconut palm area } & Surface & 5.1 & 5.6 & 5.3 & 5.3 & 0.21 \\
\hline & & Subsurface & 5.1 & 5.8 & 5.7 & 5.5 & 0.31 \\
\hline & \multirow{2}{*}{ Oil palm area } & Surface & 5.2 & 6.1 & 5.9 & 5.7 & 0.39 \\
\hline & & Subsurface & 5.4 & 6.1 & 5.7 & 5.7 & 0.29 \\
\hline \multirow{8}{*}{$\mathrm{DO}, \mathrm{mg} / \mathrm{L}$} & \multirow{2}{*}{ Populated area } & Surface & 2.68 & 3.68 & 4.412 & 3.6 & 0.71 \\
\hline & & Subsurface & 3.15 & 4.48 & 5.98 & 4.5 & 1.16 \\
\hline & \multirow{2}{*}{ Paddy cultivation } & Surface & 2.73 & 5.44 & 2.206 & 3.5 & 1.42 \\
\hline & & Subsurface & 2.95 & 5.12 & 4.728 & 4.3 & 0.94 \\
\hline & \multirow[t]{2}{*}{ Coconut palm area } & Surface & 2.58 & 4.24 & 4.306 & 3.7 & 0.80 \\
\hline & & Subsurface & 2.89 & 4.16 & 4.57 & 3.9 & 0.72 \\
\hline & \multirow[t]{2}{*}{ Oil palm area } & Surface & 3.4 & 3.84 & 2.891 & 3.4 & 0.39 \\
\hline & & Subsurface & 2.93 & 4.96 & 2.932 & 3.6 & 0.96 \\
\hline \multirow{8}{*}{$\mathrm{BOD}, \mathrm{mg} / \mathrm{L}$} & \multirow{2}{*}{ Populated area } & Surface & 1.262 & 1 & 1.036 & 1.1 & 0.12 \\
\hline & & Subsurface & 2.42 & 1 & 1.568 & 1.7 & 0.58 \\
\hline & \multirow[t]{2}{*}{ Paddy cultivation } & Surface & 2.04 & 1.08 & 1.022 & 1.4 & 0.47 \\
\hline & & Subsurface & 1.93 & 1.12 & 1.338 & 1.5 & 0.34 \\
\hline & \multirow[t]{2}{*}{ Coconut palm area } & Surface & 1.95 & 1.36 & 1.486 & 1.6 & 0.25 \\
\hline & & Subsurface & 1.63 & 1.08 & 1.414 & 1.4 & 0.23 \\
\hline & \multirow[t]{2}{*}{ Oil palm area } & Surface & 2.71 & 2.6 & 1.315 & 2.2 & 0.63 \\
\hline & & Subsurface & 2.42 & 2.4 & 1.43 & 2.1 & 0.46 \\
\hline \multirow{8}{*}{$\mathrm{COD}, \mathrm{mg} / \mathrm{L}$} & \multirow{2}{*}{ Populated area } & Surface & 7.8 & 8 & 8 & 7.9 & 0.09 \\
\hline & & Subsurface & 8.13 & 10.45 & 10.13 & 9.6 & 1.03 \\
\hline & \multirow[t]{2}{*}{ Paddy cultivation } & Surface & 9.45 & 9.71 & 7.57 & 8.9 & 0.95 \\
\hline & & Subsurface & 8.06 & 13.97 & 9.06 & 10.4 & 2.58 \\
\hline & \multirow[t]{2}{*}{ Coconut palm area } & Surface & 8.2 & 6.3 & 8.2 & 7.6 & 0.90 \\
\hline & & Subsurface & 9.45 & 7.78 & 9.7 & 9.0 & 0.85 \\
\hline & \multirow[t]{2}{*}{ Oil palm area } & Surface & 9.7 & 8.43 & 10.45 & 9.5 & 0.83 \\
\hline & & Subsurface & 11.4 & 9.39 & 11.4 & 10.7 & 0.95 \\
\hline \multirow{8}{*}{$\begin{array}{c}\text { Chloride, } \\
\text { mg/L }\end{array}$} & Populated area & Surface & 2.75 & 0.499 & 2.317 & 1.9 & 0.98 \\
\hline & & Subsurface & 3.54 & 0.482 & 2.77 & 2.3 & 1.30 \\
\hline & Paddy cultivation & Surface & 2.516 & 0.765 & 1.77 & 1.7 & 0.72 \\
\hline & & Subsurface & 2.75 & 0.747 & 1.77 & 1.8 & 0.82 \\
\hline & Coconut palm area & Surface & 3.76 & 1.01 & 2.87 & 2.5 & 1.15 \\
\hline & & Subsurface & 7.57 & 0.99 & 3.54 & 4.0 & 2.71 \\
\hline & Oil palm area & Surface & 5.27 & 0.88 & 5.317 & 3.8 & 2.08 \\
\hline & & Subsurface & 8.79 & 0.95 & 5.317 & 5.0 & 3.21 \\
\hline & Populated area & Surface & 5 & 0.9 & 4.2 & 3.4 & 1.77 \\
\hline & & Subsurface & 6.4 & 0.9 & 5 & 4.1 & 2.33 \\
\hline & Paddy cultivation & Surface & 4.6 & 1.4 & 3.2 & 3.1 & 1.31 \\
\hline & & Subsurface & 5 & 1.4 & 3.2 & 3.2 & 1.47 \\
\hline Salinity, g/L & Coconut palm area & Surface & 6.8 & 1.9 & 5.2 & 4.6 & 2.04 \\
\hline & & Subsurface & 9.5 & 1.8 & 6.4 & 5.9 & 3.16 \\
\hline & Oil palm area & Surface & 9.5 & 1.6 & 9.6 & 6.9 & 3.75 \\
\hline & & Subsurface & 15.9 & 1.7 & 9.6 & 9.1 & 5.81 \\
\hline
\end{tabular}




\begin{tabular}{|c|c|c|c|c|c|c|c|}
\hline 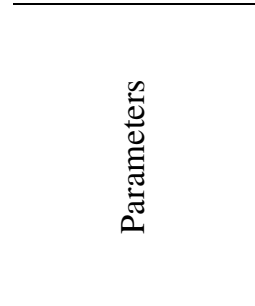 & Land use & & 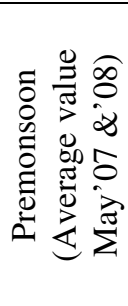 & 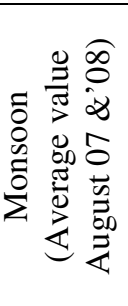 & 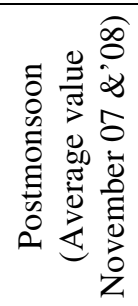 & 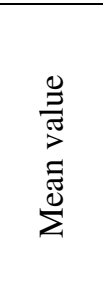 & 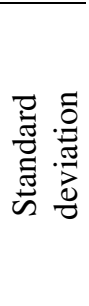 \\
\hline \multirow{8}{*}{ Phosphate, mg/L } & \multirow[t]{2}{*}{ Populated area } & Surface & 0.279 & 0.002 & 0.299 & 0.2 & 0.14 \\
\hline & & Subsurface & 0.274 & 0.005 & 0.274 & 0.2 & 0.13 \\
\hline & \multirow[t]{2}{*}{ Paddy cultivation } & Surface & 0.302 & 0.005 & 0.299 & 0.2 & 0.14 \\
\hline & & Subsurface & 0.399 & 0.084 & 0.303 & 0.3 & 0.13 \\
\hline & \multirow[t]{2}{*}{ Coconut palm area } & Surface & 0.244 & 0.14 & 0.269 & 0.2 & 0.06 \\
\hline & & Subsurface & 0.213 & 0.002 & 0.254 & 0.2 & 0.11 \\
\hline & \multirow[t]{2}{*}{ Oil palm area } & Surface & 0.274 & 0.11 & 0.284 & 0.2 & 0.08 \\
\hline & & Subsurface & 0.316 & 0.14 & 0.416 & 0.3 & 0.11 \\
\hline \multirow{8}{*}{ Fluoride, mg/L } & \multirow[t]{2}{*}{ Populated area } & Surface & 0.05 & 0.005 & 0.04 & 0.032 & 0.02 \\
\hline & & Subsurface & 0.04 & 0.007 & 0.03 & 0.026 & 0.01 \\
\hline & \multirow[t]{2}{*}{ Paddy cultivation } & Surface & 0.06 & 0.005 & 0.05 & 0.038 & 0.02 \\
\hline & & Subsurface & 0.04 & 0.005 & 0.03 & 0.025 & 0.01 \\
\hline & \multirow[t]{2}{*}{ Coconut palm area } & Surface & 0.05 & 0.007 & 0.04 & 0.032 & 0.02 \\
\hline & & Subsurface & 0.05 & 0.007 & 0.04 & 0.032 & 0.02 \\
\hline & \multirow[t]{2}{*}{ Oil palm area } & Surface & 0.06 & 0.005 & 0.04 & 0.035 & 0.02 \\
\hline & & Subsurface & 0.06 & 0.002 & 0.04 & 0.034 & 0.02 \\
\hline \multirow{8}{*}{$\begin{array}{c}\text { Alkalinity, } \\
\text { mg/L }\end{array}$} & \multirow[t]{2}{*}{ Populated area } & Surface & 0.4 & 1 & 0.7 & 0.7 & 0.24 \\
\hline & & Subsurface & 0.4 & 0.8 & 0.6 & 0.6 & 0.16 \\
\hline & \multirow[t]{2}{*}{ Paddy cultivation } & Surface & 0.4 & 0.6 & 0.7 & 0.6 & 0.12 \\
\hline & & Subsurface & 0.4 & 0.4 & 0.7 & 0.5 & 0.14 \\
\hline & \multirow[t]{2}{*}{ Coconut palm area } & Surface & 0.4 & 0.4 & 0.7 & 0.5 & 0.14 \\
\hline & & Subsurface & 0.4 & 0.6 & 0.8 & 0.6 & 0.16 \\
\hline & \multirow[t]{2}{*}{ Oil palm area } & Surface & 0.4 & 0.4 & 0.8 & 0.5 & 0.19 \\
\hline & & Subsurface & 0.4 & 0.4 & 0.7 & 0.5 & 0.14 \\
\hline \multirow{8}{*}{ T.Hard, mg/L } & \multirow[t]{2}{*}{ Populated area } & Surface & 48 & 10 & 24 & 27.3 & 15.69 \\
\hline & & Subsurface & 44 & 16 & 22 & 27.3 & 12.04 \\
\hline & \multirow[t]{2}{*}{ Paddy cultivation } & Surface & 33 & 10 & 24 & 22.3 & 9.46 \\
\hline & & Subsurface & 30 & 26 & 24 & 26.7 & 2.49 \\
\hline & \multirow[t]{2}{*}{ Coconut palm area } & Surface & 43 & 16 & 22 & 27.0 & 11.58 \\
\hline & & Subsurface & 33 & 26 & 26 & 28.3 & 3.30 \\
\hline & \multirow[t]{2}{*}{ Oil palm area } & Surface & 41 & 14 & 26 & 27.0 & 11.05 \\
\hline & & Subsurface & 38 & 14 & 24 & 25.3 & 9.84 \\
\hline \multirow{8}{*}{ Nitrate, mg/L } & \multirow[t]{2}{*}{ Populated area } & Surface & 0.221 & 0.121 & 0.23 & 0.2 & 0.05 \\
\hline & & Subsurface & 0.269 & 0.169 & 0.27 & 0.2 & 0.05 \\
\hline & \multirow[t]{2}{*}{ Paddy cultivation } & Surface & 0.352 & 0.252 & 0.327 & 0.3 & 0.04 \\
\hline & & Subsurface & 0.336 & 0.236 & 0.369 & 0.3 & 0.06 \\
\hline & \multirow[t]{2}{*}{ Coconut palm area } & Surface & 0.327 & 0.127 & 0.252 & 0.2 & 0.08 \\
\hline & & Subsurface & 0.317 & 0.117 & 0.236 & 0.2 & 0.08 \\
\hline & \multirow[t]{2}{*}{ Oil palm area } & Surface & 0.8 & 0.5 & 0.8 & 0.7 & 0.14 \\
\hline & & Subsurface & 0.6 & 0.4 & 0.7 & 0.6 & 0.12 \\
\hline
\end{tabular}


Alkalinity of water lies between $0.4-1 \mathrm{mg} / \mathrm{L}$. Alkalinity is higher in the Post monsoon period in all sites except Populated area which is higher during monsoon. Though there is seasonal variation it is within the permissible limit.

Hardness in water is due to the natural accumulation of salts from contact with the soil and geological formations or it may enter from the direct pollution by human activities. In the present study hardness ranges from $10-48 \mathrm{mg} / \mathrm{L}$. Total hardness is comparatively high in populated area especially in surface water during pre monsoon period, but it is lowered in the surface water of populated area and Paddy field area during monsoon period. An increase in hardness is mainly due to agricultural run off. In short hardness is higher in the pre monsoon period in all sites, possibly due to the influx of sea water and lowered hardness in all the sites during monsoon rains.

Salinity in different site areas lay between $0.90-15.89595 \mathrm{mg} / \mathrm{L}$. Salinity is higher in oil palm area. In the oil palm area, subsurface water is more saline than the surface water. All the sites showed an increased level of salinity during pre monsoon than monsoon and post monsoon periods. It is also due to the influx of sea water into the river. Salinity affected the solubility of oxygen.

Generally unpolluted water contains low concentration of chlorides lower than $10 \mathrm{mg} / \mathrm{L}$. Permissible level of chloride is $250 \mathrm{mg} / \mathrm{L}$. In the present study the amount of chloride varies from $0.499-8.79 \mathrm{mg} / \mathrm{L}$. It is within the permissible limit. The chloride content is higher in the oil palm area especially in the subsurface water and lesser in the Paddy field area.

In the present study nitrate level lies between $0.121-0.8 \mathrm{mg} / \mathrm{L}$. Nitrate concentration is high in oil palm area especially in surface waters and almost same during pre monsoon and post monsoon periods. This may be due to the application of nitrogenous fertilizers and decay of straw. There is an increasing concern about nitrogen $(\mathrm{N})$ pollution of surface water for which agricultural activities can be identified as non-point sources. Drainage from manure storage sites in large-scale, livestock husbandry operations and drainage from landfill sites are considered to be point sources of nitrogen pollution that severely affect the quality of stream water ${ }^{8}$. The water in this site showed eutrophication.

The fluoride concentration in natural waters varies from 0.05 to $100 \mathrm{mg} / \mathrm{L}$. Although in most situations they are less than $0.1 \mathrm{mg} / \mathrm{L}$. In the study sites, fluoride concentration lies between $0.002-0.06 \mathrm{mg} / \mathrm{L}$. Fluoride concentration is higher in Paddy field area \& oil palm area during the pre monsoon period and lowers in monsoon period. In all the sites, surface water shows more fluoride concentration than the subsurface water. Fluoride level showed seasonal variation.

The phosphate concentrations in different site areas lies between $0.002-0.399 \mathrm{mg} / \mathrm{L}$. Paddy field area \& oil palm area showed increased level of phosphate. Water collected from the agricultural area showed slight increase in phosphate than the samples collected from the other sites. This is due to the addition of phosphate containing fertilizers and pesticides in the agricultural field.

Oxygen content of water varies with temperature, salinity, turbulence, photosynthetic activity of algae and higher plants atmospheric pressure etc. Concentrations of DO in unpolluted waters are usually about $8-10 \mathrm{mg} / \mathrm{L}$. In the present study DO level range between 2.206-5.98 mg/L. DO is greatly reduced in all the sites during pre monsoon period. Its value depleted significantly in oil palm area, where water flow is slow. The increased rate of salinity, sewage and agricultural run off from the paddy fields etc. may be the causes of depletion of DO in the river. Rapid increase in algae also leads to the depletion of DO. 
BOD refers to the amount of oxygen used by microorganisms in the aerobic oxidation of organic matter. Therefore, BOD increases with the amount of organic matter in water. In the present study BOD lies between 1-2.71 mg/L. Present study revealed that BOD is higher in the surface and subsurface water of oil palm area during pre monsoon period. Increased level of BOD shows pollution of water due to organic wastes. The water is considered fairly pure with BOD of $3 \mathrm{mg} \mathrm{O}_{2} / \mathrm{L}$ and of doubtful purity when BOD value ${ }^{9}$ reaches $5 \mathrm{mg} \mathrm{O}_{2} / \mathrm{L}$.

The concentration of COD is usually less than 20 parts per million in unpolluted waters. Higher values may indicate pollution from domestic sewage and industrial effluents. In the present study COD varies from 7.57-13.97 mg/L. COD is higher in Paddy field area and oil palm area.

To determine the significant variation in different parameters with respect to the three different months, ANOVA test was done. The hypothesis selected for the test was "there is no significant variation". The table value of " $\mathrm{F}$ at $5 \%$ level of significance for $\mathrm{V}_{1}=2$ and $\mathrm{V} 2=9$ is 4.26 . If the calculated value of ' $\mathrm{F}$ ' is greater than the table value, the hypothesis is rejected. Hence there is significant difference. If the calculated value of ' $F$ ' is less than the table value, the hypothesis is accepted i.e., there is no significant difference. From the ANOVA test it is clear that there is significant variation in the levels of Turbidity, $\mathrm{pH}$, Total hardness, Phosphate, Salinity, Chloride and DO with respect to the three seasons. The levels of other factors are not significantly different with respect to different seasons.

\section{Conclusion}

Results of the study indicated that water in Pennar River is highly contaminated and not safe for drinking .It was further observed that farmers of the area are very illiterate and they are using all sorts of chemical fertilizers and pesticides. People of the locality use non-sanitary latrines. Open defecation, water-logging environment, poor drainage facilities and unscrupulous dumping of domestic wastes resulted in the deterioration of water quality in the study area. The study also revealed that poor quality of drinking water was recorded as the major risk factor for the large-scale water-borne diseases in the area.

The river is subjected to natural contamination by activities of man. We have the responsibility to protect rivers. We should give awareness to people about the need for protecting the river and consequences of pollution. Strict legal action should be taken against those who contaminate the river.

\section{Acknowledgment}

The authors are grateful to University Grants Commission for providing financial assistance and Principal, K E College for providing laboratory facility to carry out the investigation.

\section{References}

1. Karn Kumar S and Harada H, J Environ Manage., 2001, 28, 483.

2. Ravichandran S, Environ Monit Assess., 2003, 87, 293-309.

3. Elizabeth Ngoye and John F Machiwa, Phys Chem Earth, 2004, 29, 1161.

4. Sarkar Amita, Singhal Vineeta and Arora M.P, J Expt Zoo India, 2002, 5(1), 107-112.

5. Prakasan V R and Joseph M.L, J Environ Biol., 2000, 21, 305.

6. Koshy Mathew and Vasudevan Nayar T, Pollut Res., 1999, 18, 501.

7. Sharma P Aushik A, Jain S and Darwara J, J Environ Biol, 2003, 24, 331.

8. Nagumo T, Woli K P and Hatano R, Japan Soil Science and Plant Nutrition, 2004, 50, 109-117.

9. Rao Sudhakar M and Mamatha P, Curr Sci., 2004, 87, 942. 


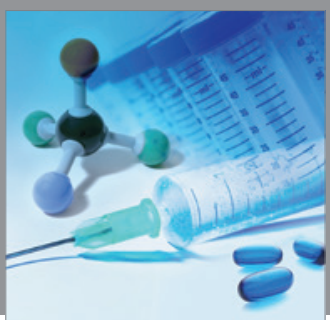

International Journal of

Medicinal Chemistry

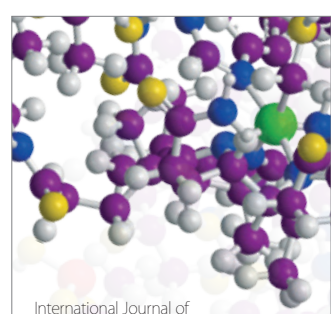

Carbohydrate Chemistry

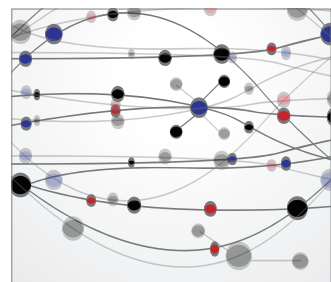

The Scientific World Journal
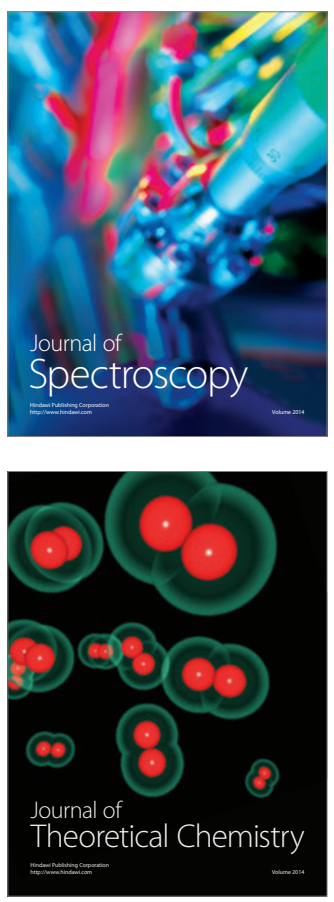
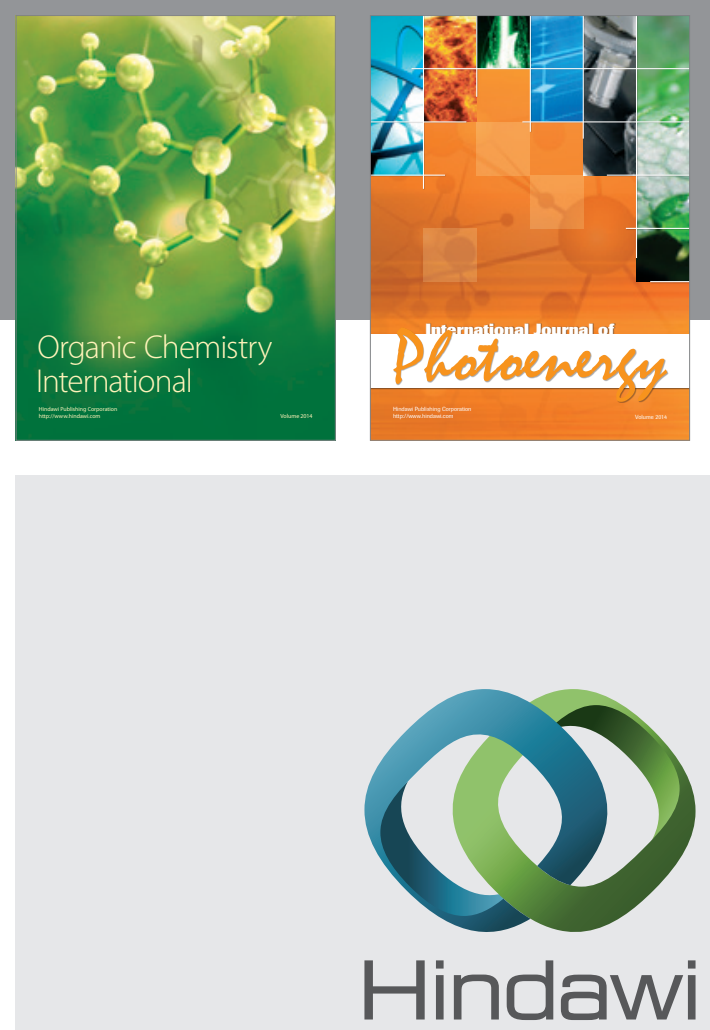

Submit your manuscripts at

http://www.hindawi.com
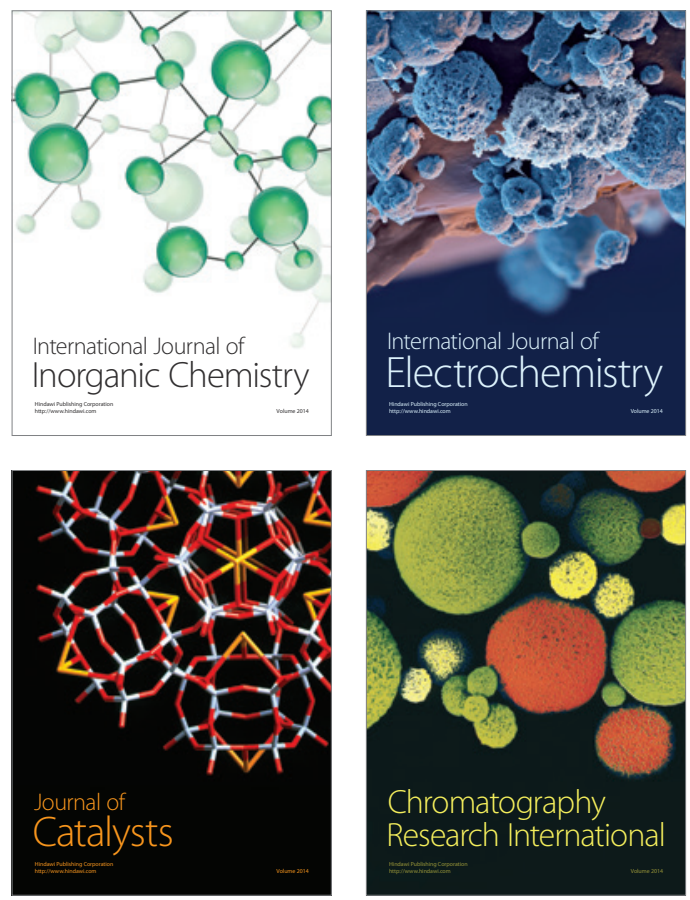
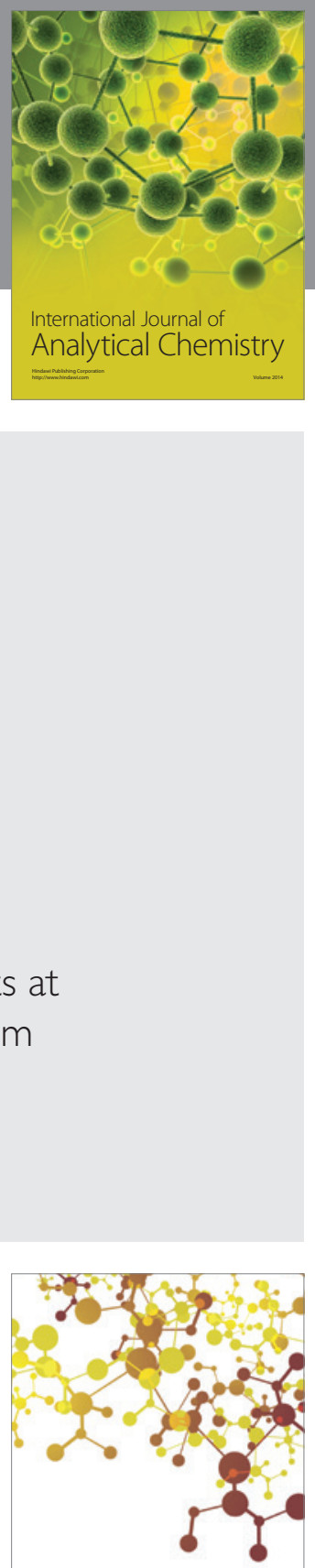

Journal of

Applied Chemistry
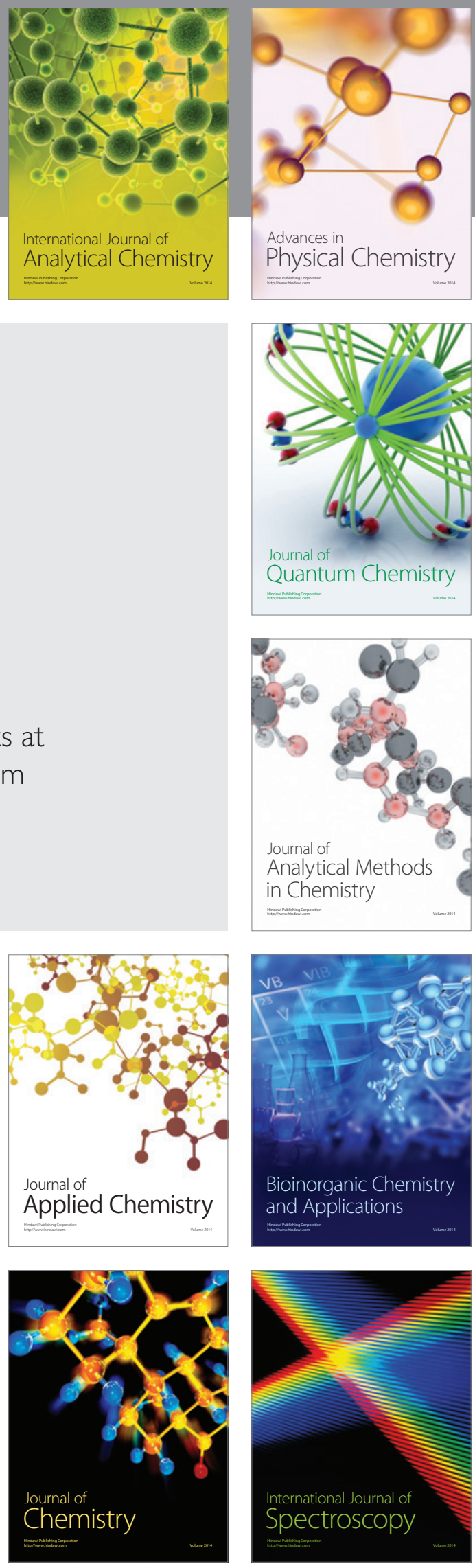